\author{
III Russian National Conference \\ "Information Technology in Biodiversity Research"
}

\title{
About potential area of Patrinia sibirica (L.) Juss. in the Southern Urals
}

\author{
Aliya G. Kutueva (a), Nikolai I. Fedorov (b), Albert A. Muldashev (c), \\ Amina H. Galeeva (d), Leniza G. Naumova (e)
}

(a) ORCID: 0000-0001-5104-188X,

Ufa Institute of Biology - subdivision of the Ufa Federal Research Centre of the Russian Academy of Sciences, 69 October prospect, 450054 Ufa, Russia (b) ORCID: 0000-0002-0167-7449,

Ufa Institute of Biology - subdivision of the Ufa Federal Research Centre of the Russian Academy of Sciences, 69 October prospect, 450054 Ufa, Russia (c) ORCID: 0000-0002-0619-4171,

Ufa Institute of Biology - subdivision of the Ufa Federal Research Centre of the Russian Academy of Sciences, 69 October prospect, 450054 Ufa, Russia (d) ORCID: 0000-0003-4249-7863,

Ufa Institute of Biology - subdivision of the Ufa Federal Research Centre of the Russian Academy of Sciences, 69 October prospect, 450054 Ufa, Russia (e) ORCID: 0000-0001-7776-0786,

Bashkir State Pedagogical University, 3-a Oktyabrskoy revolyutsii street, 450008 Ufa, Russia

\begin{abstract}
Patrinia sibirica is a mountain forest-steppe species. It is also a relic of the Pleistocene complex in the Southern Urals and included into the Red Data Books of the Republic of Bashkortostan and the Chelyabinsk Oblast. The potential range of Patrinia sibirica of the Southern Urals was analyzed using the maximum entropy method. Data on 32 georeferenced localities of this species in the Southern Urals and 30 localities in Western and Eastern Siberia were used as source material. Modeling of the potential distribution of the species was carried out using the program MaxEnt. The CHELSA database BIOCLIM set of climate variables and GMTED2010 global digital elevation model data were used as environment predictors. Habitat suitability was most influenced by 4 variables: seasonality of temperature, isothermality, maximum altitude, and precipitation in the warmest quarter. According to the model, the largest areas of suitable habitat for this species are concentrated along the peaks and upper slopes of the largest ridges of the South Ural Mountains and reach the northern boundary of Taganay National Park. The modeling has revealed suitable habitats in a wood-steppe zone of the Trans-Ural which are confined to the outcrops of granite and quartzite rocks among petrophytic and shrub steppes. The unavailability of the species in some places with suitable conditions for its growth may be due to its overgrowth by forest vegetation during the expansion of forests in the middle of the Holocene and, in some cases, high anthropogenic impact.
\end{abstract}

Keywords: CHELSA, distribution of species, habitat suitability, MaxEnt, Patrinia sibirica (L.) Juss., Pleistocene relic

(C) 2020 Aliya G. Kutueva, Nikolai I. Fedorov, Albert A. Muldashev,

Amina H. Galeeva, Leniza G. Naumova

This is an open access article distributed under the terms of the Creative Commons Attribution

License (CC BY 4.0), which permits unrestricted use, distribution, and reproduction in any medium, provided the original author and source are credited.

Published by Ural Federal University and peer-reviewed under responsibility of BDI-2020 (III Russian National Conference "Information Technology in Biodiversity Research")

\footnotetext{
* Corresponding author. Tel.: +79373609760; e-mail address: aliacutueva@mail.ru
} 


\section{Introduction}

Patrinia sibirica (L.) Juss. is a north and central Asian mountain forest-steppe grassy species distributed in the Western and Eastern Siberia, the Russian Far East, Central Asia, Jungaria, Mongolia. In the Southern and Central Urals it is a relic of the Pleistocene complex (Gorchakovsky and Shurova 1982) and is included in the Red Data Books of the Chelyabinsk Oblast (Lagunov 2017) and the Republic of Bashkortostan (Mirkin 2011). This species has conservation status "a rare species with a naturally low population, found in a limited area" in the Red Data Book of the Republic of Bashkortostan. P. sibirica grows on stony, well-insulated mountain slopes, upland habitats on tops of the ridges and also in the rocky steppe communities (Gorchakovsky 1975). Purpose of research is analysis of potential distribution of $P$. sibirica species in the Southern Urals.

To our knowledge, no previous studies have been done to address the ecological niche of Patrinia sibirica in the Southern Urals. Accordingly, predicting its habitat suitability, in order to estimate its spatial geographic distribution, and exploring suitable persistence conditions are critical to conserving this plant species. Among the algorithms of SDM MaxEnt method was chosen because of its many advantages including: the input data on species can be only points of presence; its prediction is stable and reliable with great accuracy, even at small sample sizes, so that the distribution of endangered species can be predicted (Phillips et al. 2006; Elith et al. 2010).

\section{Methods}

The coordinates of georeferenced $P$. sibirica localities, including 32 localities in the Southern Urals and 30 localities in Western and Eastern Siberia, were used as the source material for modeling. The current distribution data of $P$. sibirica was collected from GBIF (GBIF 2019) and literature data (Telyatnikov 2014; Zibzeev and Nedovesova 2014; Karimova et al. 2016).

Twenty-two variables were retrieved as predictors for modelingthe potential environmental niche of $P$. sibirica based on its current presence dataset. In particular, 19 bioclimatic layers were obtained from CHELSA BIOCLIM (CHELSA 2019; Karger et al. 2017) and three variables of elevation (maximum, minimum and mean elevation) (Digital 2019). In order to avoid the high similarity among these environmental variables, we removed the factors that the Pearson's correlation coefficient is greater than or equal to 0.8 .

We used MaxEnt v3.4.1k for distribution modeling of the species (Phillips et al. 2006, 2018). The MaxEnt method is based on the principle of niche modeling, which assumes that under certain known conditions the system with the highest entropy is closest to its true state (Elith et al. 2010). The AUC indicator was used for statistical evaluation of the model. The reliability of predictors' contribution to the model was assessed using the permutation importance (Mean Decrease Accuracy) and «jackknife» tests (Phillips 2017). The values of habitat suitability on the MaxEnt map model from 0.90 to 1.00 were considered very high, 0.75 to 0.89 as relatively high, 0.50 to 0.74 as moderate, and lower than 0.50 as low.

\section{Results}

The model showed high levels of predictive performances (AUC-training sample are 0.995 and for the AUC-test sample are 0.973) (Swets 1988). After the removal of highly correlated variables, 5 climate variables (bio4 is temperature seasonality 
(the standard deviation of the average monthly temperature), bio3 is isothermality, bio7 is temperature annual range, bio17 is precipitation of driest quarter, bio 18 is precipitation of warmest quarter) and the maximum altitude remained. Four of the six variables had high contribution values: temperature seasonality, isothermality, maximum altitude and precipitation of warmest quarter, which together in the model determine $71.4 \%$ influence on the $P$. sibirica distribution.

Localities from different parts of the species range, including those outside the Southern Urals, were added to the model. In this regard, the characterization of highly suitable habitats represents the ecological and cenothic optimum of the species, which may be located outside the immediately considered species' range. The analysis of the distribution of habitat suitability along the gradients of 4 major environmental factors used as model predictors has shown that all distributions are described by singlehumped response curves. Temperature seasonality (bio4) of high-suitable habitat conditions is in the range of $11.4-11.6^{\circ} \mathrm{C}$. These values of this predictor are typical for the northern part of the Pre-Urals and the South Urals Mountains. Optimum conditions of the species growth are in the interval of 1 800-2 $800 \mathrm{~m}$ of the maximum height above sea level, which means it is in the altitude range higher than the highest mountain peaks of the South Ural Mountains. At these altitudes the species can be found in Siberia, where P. sibirica is not a rare species. Isothermality (bio3) quantifies how large the daily temperatures oscillate relative to the annual oscillations. The most optimal habitat suitability for the species is in a narrow range of strong fluctuations from 2.00 to 2.03 times. These oscillations are typical for mountain and tundra habitats. The precipitation of warmest quarter (bio 18) of high-suitable habitats varies in the range of 305.50-361.10 mm. The lower limit of variation corresponds to the level of precipitation in localities where the species grows in the mountains of the Southern Urals. Precipitation is much lower in the Trans-Urals, but moderate suitable habitats prevail there. This is probably also due to the fact that rocky habitats often demonstrate great edaphic heterogeneity, providing a mosaic of small-scale variations of ecologically significant variables, including soil moisture (Rossington et al. 2018; Byrne et al. 2019; Corlett and Tomlinson 2020) and small-scale temperature variability (Corlett and Tomlinson 2020).

Thus, the ecological and cenothic optimum of the species is not in the field of distribution of mountain forest-steppe localities, as it is noted in publications devoted to the growth of this species in the Southern Urals, but in mountain and tundra habitats. This is confirmed by its fairly wide distribution in the mountains of Western and Eastern Siberia and by its isolated locations in the tundra of the Magadan Oblast.

To evaluate each variable's contribution we performed a "jackknife" test. It is based on sequentially disabling variables and creating models with the rest of the predictors. "Jackknife" test showed that two variables have the highest value in the model construction: temperature seasonality (bio4) and isothermality (bio3). The maximum altitude in the jackknife test has a relatively small individual impact, despite the significant contribution to the model construction using all predictors (Fig. 1). 


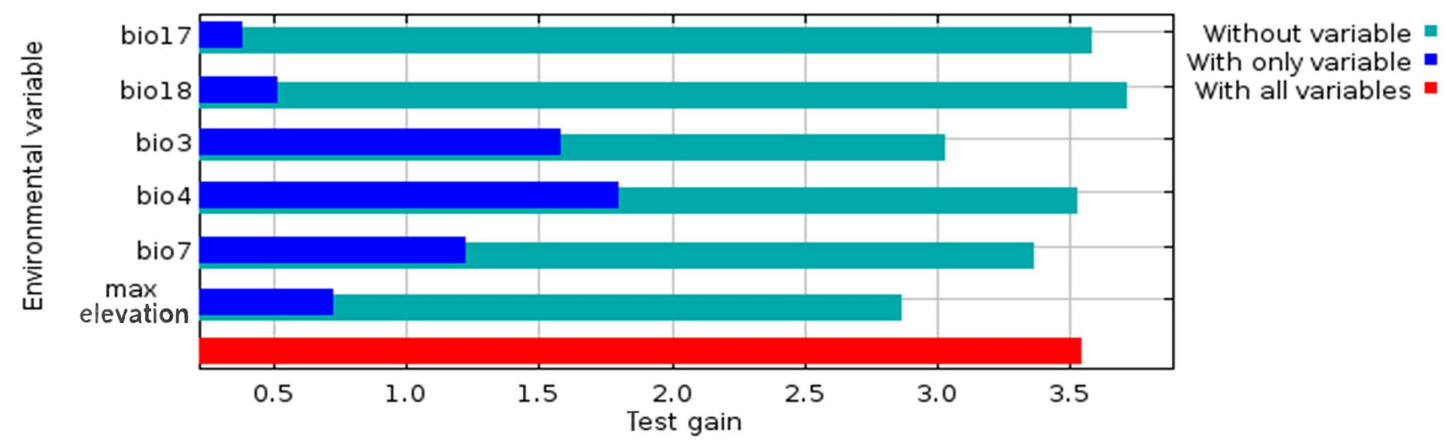

Figure 1. The "jackknife" test for evaluating the relative importance of environmental variables for Patrinia sibirica (L.) Juss.

"bio3" is isothermality, "bio4" is temperature seasonality,

"bio7" is temperature annual range, "bio 17" is precipitation of driest quarter,

"bio 18 " is precipitation of warmest quarter, "max elevation" is maximum altitude.

\section{Discussion}

According to the model, in the Republic of Bashkortostan the areas most suitable for the growth of this species are concentrated on tops and the top parts of slopes of large ridges of the South Ural Mountains (Iremel mountain massif, Mashaq ridge, etc.). In the south of central part of the Southern Urals these habitats are restricted by the Shatak Ridge, along the eastern macroslope of the South Urals. They are located in a narrow strip 35-40 km to the south and along the spur of the South Ural Mountains on the Irendyk Ridge, and they enter the steppe zone in the Trans-Urals. Identified localities of $P$. sibirica in the mountainous forest zone are confined to rocky screes at the border or above the forest spread. The largest localities in terms of area of this species are concentrated in the elevated part of the Southern Urals, as well as on the lower Irendyk Range and its spurs (The Mount Shartymka) on the border of the Republic of Bashkortostan and the Chelyabinsk Oblast. Despite the high habitat suitability, P. sibirica was not found in the southern parts of the eastern macro-slope of the Southern Urals and the Irendyk Range. Probably this is because at the time of the warmest and mildest climate (in Holocene, about 5-6 thousand years ago) (Khotinsky et al. 1982) most of these habitats may have been occupied by other (primarily woody) vegetation with the high level of competition that caused the species to fall out. In the north, mass distribution of areas with habitat suitability ends at the northern border of Taganay National Park. There are no suitable habitats for this species in the Cis-Ural. On the western macroslope of the South Ural Mountains there are some very narrow areas with high suitability for this species to grow on the Alatau Range. In the TransUrals $P$. sibirica occurs in the forest-steppe zone at the tops of small mountains on the outcrops of granite and quartzite rocks among petrophyte and shrub steppes in the eastern foothills of the Southern Urals. In these habitats the localities of the species usually occupy a small area, and growth conditions are estimated by the model in the range of $0.75-0.85$. There are two exceptions to this. One of the habitats has low suitability for growing conditions $(0.49)$ because the habitat is much smaller than the raster resolution. It is a narrow ten-meter strip of crushed stone soil, which is about $50 \mathrm{~m}$ long among the petrophyte steppe and is actually characterized by high habitat suitability. The second locality is a ridge of a mountain on the right bank of the Shartymka River, it is about $40 \mathrm{~m}$ wide and about $800 \mathrm{~m}$ long, it has a moderate habitat suitability (0.61) (Fig. 2). 


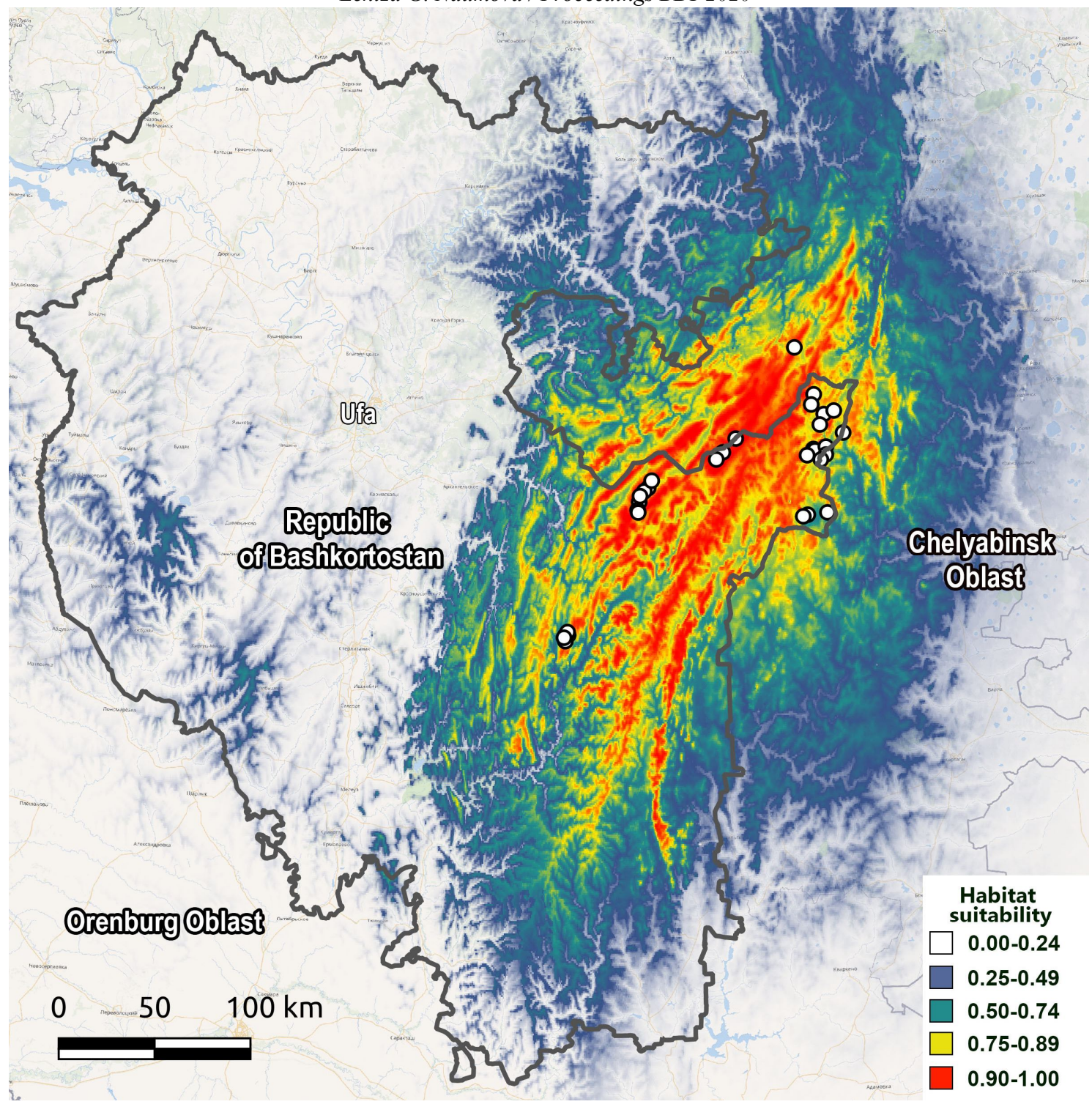

Figure 2. Predicted potential distribution of Patrinia sibirica (L.) Juss.

The map source is Wikimedia Maps (2020).

The majority of localities have the area less than 1 hectare, and only eight of them have the area of more than 4 hectares (all of them are located at heights above $1250 \mathrm{~m}$ above sea level). That is connected with features of ecology of the species and its grows on open rocky habitats which stains meet on tops of South Ural Mountains and tops of hills in mountain wood steppes of the Trans-Ural. Thus, these localities occupy insignificant area within the potential range.

\section{Conclusion}

Thus, the constructed model characterizes quite clearly the habitat suitability and potential range of $P$. sibirica. The potential range of the species is slightly wider than the area of its known locations, which is related to its possible extinction in these localities during the most suitable period for vegetation in the Holocene and in some cases with high anthropogenic impact (grazing and quarrying). The analysis of potential distribution has shown that the ecological and cenothic optimum of $P$. sibirica is not in the area of distribution of mountain forest-steppe localities, but in mountain and tundra habitats. The obtained results can be used to select priority localities for the 
development of conservation measures taking into account the habitat suitability of the species.

\section{Acknowledgements}

This work was carried out as part of Government Contract of the Ministry of Education and Science of Russia No. 075-00326-19-00 on topic No. AAAA-A18118022190060-6 and with financial support from the Russian Foundation for Basic Research as part of scientific project No. 19-34-90028.

\section{References}

Byrne M, Krauss S, Millar M, Elliott C, Coates D, Yates C, Binks R, Nevill P, Nistelberger H, Wardell-Johnson G, Robinson T, Butcher R, Barrett M, Gibson N (2019) Persistence and stochasticity are key determinants of genetic diversity in plants associated with banded iron formation inselbergs. Biological Reviews 94 (3): 753-772. https://doi.org/10.1111/brv.12477.

CHELSA BIOCLIM (2019) http://chelsa-climate.org/bioclim/ [Accessed on 07.05.2019]

Corlett RT, Tomlinson KW (2020) Climate Change and Edaphic Specialists: Irresistible Force Meets Immovable Object? Trends in Ecology \& Evolution 35 (4): 367-376. https://doi.org/10.1016/j.tree.2019.12.007.

Digital terrain model (2019) https://topotools.cr.usgs.gov/gmted_viewer/viewer.htm [Accessed on 02.06.2019]

Elith J, Phillips SJ, Hastie T, Dudík M, Chee YE, Yates CJ (2010) A statistical explanation of MaxEnt for ecologists. Diversity and Distributions 17: 43-57.

GBIF.org (2019) GBIF Occurrence Download https://doi.org/10.15468/dl.fswlyt [Accessed on 08.04.2019]

Gorchakovskii PL (1975) Rastitel'nyi mir vysokogornogo Urala [The plant world of the Ural mountains]. Nauka, Moscow, 284 pp. [in Russian].

Gorchakovsky PL, Shurova EA (1982) Redkiye i ischezayushchiye rasteniya Urala i Priural'ya [Rare and endangered plants of the Urals and the Cisurals]. Nauka, Moscow, 208 pp. [in Russian].

Karger DN, Conrad O, Böhner J, Kawohl T, Kreft H, Soria-Auza RW, Zimmermann NE, Linder HP, Kessler M (2017) Climatologies at high resolution for the Earth's land surface areas. Scientific Data 4: 170122. https://doi.org/10.1038/ sdata.2017.122.

Karimova OA, Mustafina AN, Golovanov YM, Abramova LM (2016) Vozrastnoy sostav tsenopopulyatsii Patrinia sibirica (Valerianaceae) na Yuzhnom Urale [Age structure of coenopopulations of Patrinia sibirica (Valerianaceae) in South Ural]. Rastitelnye Resursy 52 (1): 49-65 [in Russian].

Khotinsky NA, Nemkova VK, Surova TG (1982) Glavnyye etapy razvitiya rastitel'nosti i klimata Urala $\mathrm{v}$ golotsene [Main stages of Ural vegetation and climate development in Holocene]. Issues of archeology of the Urals 16: 145-153 [in Russian]. 
Lagunov AV (Ed.) (2017) Krasnaya kniga Chelyabinskoy oblasti: zhivotnyye, rasteniya, griby [The Red Data Book of the Chelyabinsk Oblast: Animals, plants, fungi]. Second Edition. Reart, Moscow, 504 pp. [in Russian].

Mirkin BM (Ed.) (2011) Krasnaya kniga Respubliki Bashkortostan [The Red Data Book of Bashkortostan Republic]. Vol. 1: The Plants and Fungi. Second Edition. MediaPrint, Ufa, 384 pp. [in Russian].

Phillips SJ (2017) A Brief Tutorial on Maxent. http://biodiversityinformatics.amnh.org/ open_source/maxent/ [Accessed on 15.06.2017]

Phillips SJ, Anderson RP, Schapire RE (2006) Maximum entropy modeling of species geographic distributions. Ecological Modelling 190: 231-259. https://doi.org/ 10.1016/j.ecolmodel.2005.03.026.

Phillips SJ, Dudík M, Schapire RE (2018) Maxent software for modeling species niches and distributions (Version 3.4.1). http://biodiversityinformatics.amnh.org/ open_source/maxent/ [Accessed on 30.03.2019]

Rossington N, Yost J, Ritter M (2018) Water Availability Influences Species Distributions on Serpentine Soils. Madroño 65 (2): 68-79. https://doi.org/10.3120/ 0024-9637-65.2.68.

Swets JA (1988) Measuring the accuracy of diagnostic systems. Science 240: 1285-1293.

Telyatnikov M Yu (2014) Sintaksonomiya driadovykh tundr i kobreziyevykh kriofitnykh lugov Vostochnogo Sayana [Syntaxonomy of dryas tundra and kobresia cryophytic meadows of the East Sayan]. Plant Life of Asian Russia 1 (13): 48-63 [in Russian].

Wikimedia Maps (2020) https://maps.wikimedia.org [Accessed on 07.05.2020]

Zibzeev EG, Nedovesova TA (2014) Syntaxa of Dryas tundra of West Sayan mountains. Turczaninowia 17 (3): 38-59. 